\title{
Surgical Anatomical Measurements of Patellar Ligaments for Blind Method of Medial Patellar Desmotomy of Cattle During Upward Patellar Fixation in Bangladesh
}

\author{
Mediciones Anatómicas Quirúrgicas del Ligamento Patelar por Técnica Ciega en la Desmotomía \\ Medial Patelar de Ganado Durante la Fijación Superior de la Patela en Bangladesh \\ "Mohammad Mejbah Uddin; "Md. Salim Reza; "Kh. Nurul Islam; ** Omar Faruk Miazi \& *** Syed Sayeem Uddin Ahmed
}

UDDIN, M. M.; REZA, S. M.; ISLAM, N. K.; MIAZI, O. F. \& AHMED, S. S. U. Surgical anatomical measurements of patellar ligaments for blind method of medial patellar desmotomy of cattle during upward patellar fixation in Bangladesh. Int. J. Morphol., 27(2):311-315, 2009.

SUMMARY: The study was aimed to determine the accurate location of giving incision and the width of the incision required to correct the problem of upward patellar fixation during blind method of medial patellar desmotomy. We took measurements of patellar ligaments in stifle joint of 50 indigenous and 50 crossbred slaughtered cattle without any apparent musculo-skeletal disorders were analysed. The average length and width of lateral, middle, and medial patellar ligaments for indigenous cattle were $9.360 \pm 0.339$ and $3.056 \pm 0.226 ; 10.230 \pm 0.382$ and $2.019 \pm 0.258 ; 10.519 \pm 0.429$ and $2.430 \pm 0.232$; for crossbred cattle $10.636 \pm 0.601$ and $3.608 \pm 0.368$; $11.580 \pm 0.724$ and $2.330 \pm 0.205 ; 12.366 \pm 0.710$ and $2.890 \pm 0.234 \mathrm{~cm}$ respectively. The average groove width for indigenous cattle and crossbred cattle between middle and medial ligament were $1.356 \pm 0.160$ and $1.828 \pm 0.186 \mathrm{~cm}$ and the highest width of groove between middle and medial patellar ligaments from the level of most cranial bulging of the cranial tibial tuberosity in the upward direction were $4.234 \pm 0.269$ and $5.645 \pm 0.358 \mathrm{~cm}$ respectively. Parameters measured were significantly different $(\mathrm{p} \leq 0.05)$ between indigenous and crossbred cattle. This study was suggested that incision should be made $4.234 \pm 0.269$ and $5.645 \pm 0.398 \mathrm{~cm}$ proximally from the level of the most cranial bulging of cranial tibial tuberosity at the groove between middle and medial patellar ligaments, $2.430 \pm 0.232$ and $2.890 \pm 0.186 \mathrm{~cm}$ the mean width of the medial ligament to be cut during blind method of medial patellar desmotomy in indigenous and crossbred cattle respectively during surgical correction of upward patellar fixation.

KEY WORDS: Surgical Anatomy; Medial Patellar Desmotomy; Upward Patellar Fixation; Cattle.

\section{INTRODUCTION}

Regional anatomy is an important branch of anatomy directly concerned with the form and relationships of all the organs present in a particular area. This is one of the foundations of clinical and surgical practice. It enables the clinicians/ surgeons to visualize details of structures relevant to the case at hand (Dyce et al., 1996).

The anatomy of the stifle joint is very important because of patellar ligaments of femoropatellar articulation. The femoropatellar joint is formed between trochlea of the femur and articular surface of the patella. Patella is connected to the cranial tibial tuberosity by patellar ligaments. The patellar ligaments are medial, middle and lateral (Getty, 1975). Medial patellar ligaments in stifle joint are surgical importance for the medial patellar desmotomy during upward patellar fixation (Tyagi \& Singh, 2001).

In bovines, most common, best and only successful treatment to correct upward fixation of the patella is the medial patellar desmotomy (Tyagi \& Singh; Ali \& Hashim, 1984; Ramakrishna, 1972). For the medial patellar desmotomy, usually stab (close/ blind) method is preferable because there are either little or no haemorrhage with a small hole from extarior, not involve suturing, rapid healing with less post operative complication, no need to give complete rest for a longer period, minimum cost of treatment and finally less time consuming (Sutradhar, 2003; Sharma et al., 1984; Marudwar \& Kulkarni, 1980). During the course of medial patellar

\footnotetext{
* Department of Anatomy and Histology, Faculty of Veterinary Medicine, Chittagong Veterinary and Animal Sciences University, Khulsi, Chittagong, Bangladesh. ** Department of Genetics and Animal Breeding, Faculty of Veterinary Medicine, Chittagong Veterinary and Animal Sciences University. Khulsi, Chittagong, Bangladesh. 
desmotomy, a slight nicking of the middle patellar did not produce any noticeable lameness, but an accidental transaction of this ligament would render the animal permanently lame (Sahu, 1971). Some (4\%) cases take about 1-2 weeks time for complete recovery after close method of medial patellar desmotomy (Sutradhar). In Some cases of blind method, two or more attempts to severe the medial patellar ligament require during incomplete severe of this ligament (Ramakrishna). In blind method, it is very important to identify the medial patellar ligament which off course not an easy task to by palpation without having the knowledge of topographic anatomy of this ligament though it becomes thick, hard and less elastic during upward fixation of patellar ligaments (Tyagi et al., 1973). Some previous work had been done on the topographic anatomical relations of ligaments of stifle joint with a view to study the medial patellar desmotomy (Sutradhar; Hossain \& Haque, 1989; Ali \& Hashim; Rahman et al., 1984). There is very little information on the exact topographical mesearements of patellar ligaments for the proficient medial patellar desmotomy. This study was designed to provide information on some clinically important parameters and topographical anatomy of three patellar ligaments, accurate site of incision for the medial patellar desmotomy from cranial tibial tuberosity and to measure the width of medial patellar ligaments to be cut during medial patellar desmotomy in indigenous cattle and crossbred cattle, Bangladesh.

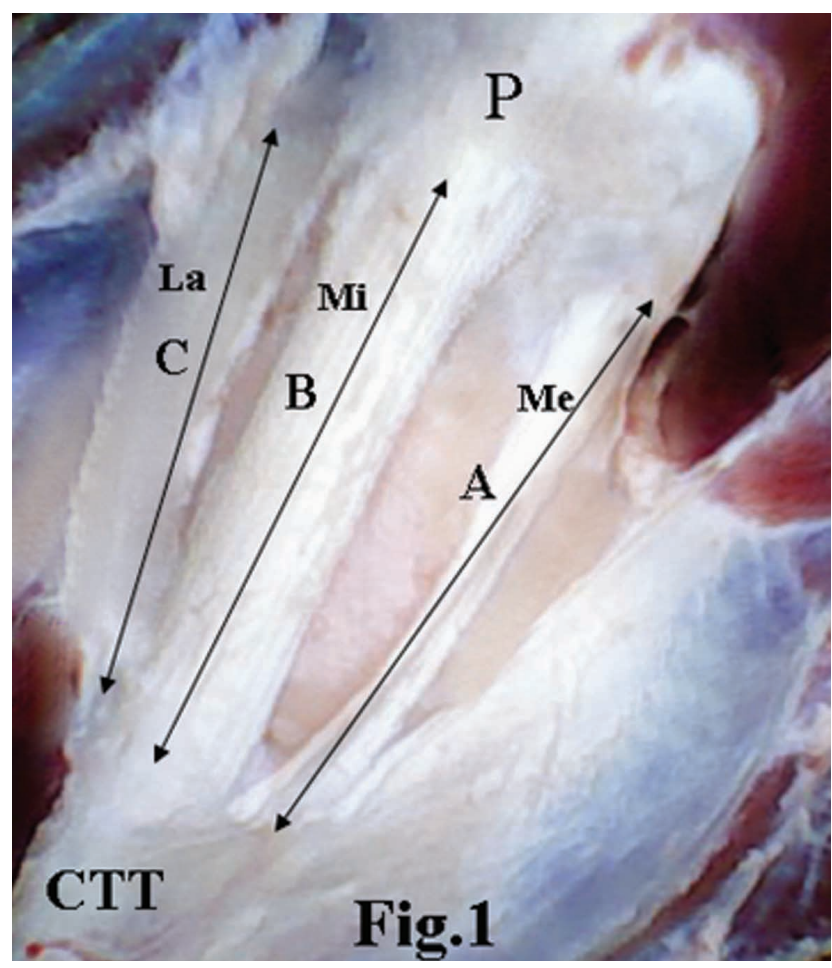

Fig.1. Measurement of length of patellar ligaments of cattle; cranial view. A. Length of medial patellar ligament (Me); B. length of middle patellar ligament (Mi); C. length of lateral patellar ligament (La); CTT. cranial tibial tuberosity; P. Patella.

\section{MATERIAL AND METHOD}

We sampled 50 stifle joints from indigenous cattle (Bos indicus) and 50 joints from crossbred cattle of both sex (male $=25$ and female $=25$ ) in the department of Anatomy and Histology at Chittagong Veterinary and Animal Sciences University, over a period of six months from October, 2007 to April, 2008. The live adult animals were firstly selected during antemortem examination at abattoir based on parameters of apparent good health and no skeletal deformation and eruption of tooth. When the cattle were slaughtered, their hind limbs were severed at hip joint after separation of skin. After that subcutaneous loose connective tissues and fascia of different layers around the stifle joint were dissected carefully to expose white glistening patellar ligaments by using scalpel and rat tooth forceps. Then the length and width of the three patellar ligaments, highest width of groove from middle to medial patellar ligaments and middle to lateral, and distance of highest groove width between middle to medial patellar ligaments from level of the most cranial bulging of cranial tibial tuberosity were done with metric rules and results were presented as means $\pm \mathrm{sd}$ and analyzed satistically by using SPSS statistical software.

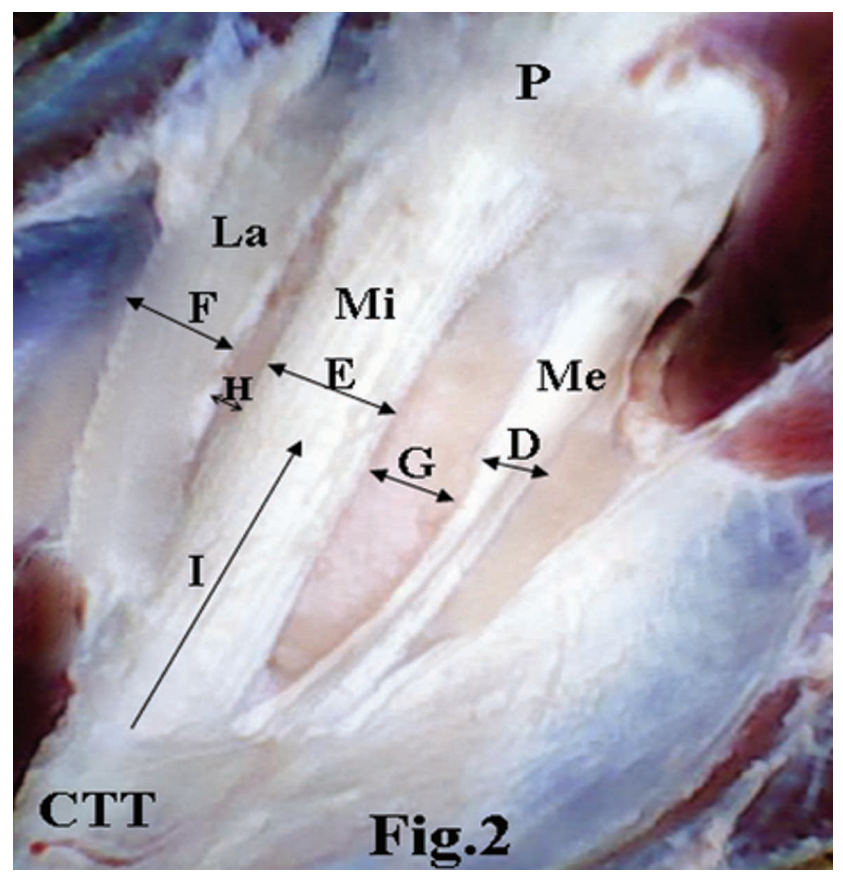

Fig. 2. Measurement of width, groove width and highest groove width between middle and medial patellar ligaments of cattle; cranial view. D. Width of medial patellar ligament (Me); E. width of middle patellar ligament (Mi); C. width of lateral patellar ligament (La); G. groove width between medial and middle patellar ligaments; H. groove width between middle and lateral patellar ligaments; I. highest groove width between middle and medial patellar ligaments of the cranial tibial tuberosity towards patella, CTT. cranial tibial tuberosity; P. Patella. 
Parameters measured in different patellar ligaments of stifle joints of indigenous and crossbred cattle were included in table I. Necessary figures were added for the better illustration of the methods of measurements (Figs. 1 and 2) and results (Figs. 3 and 4).

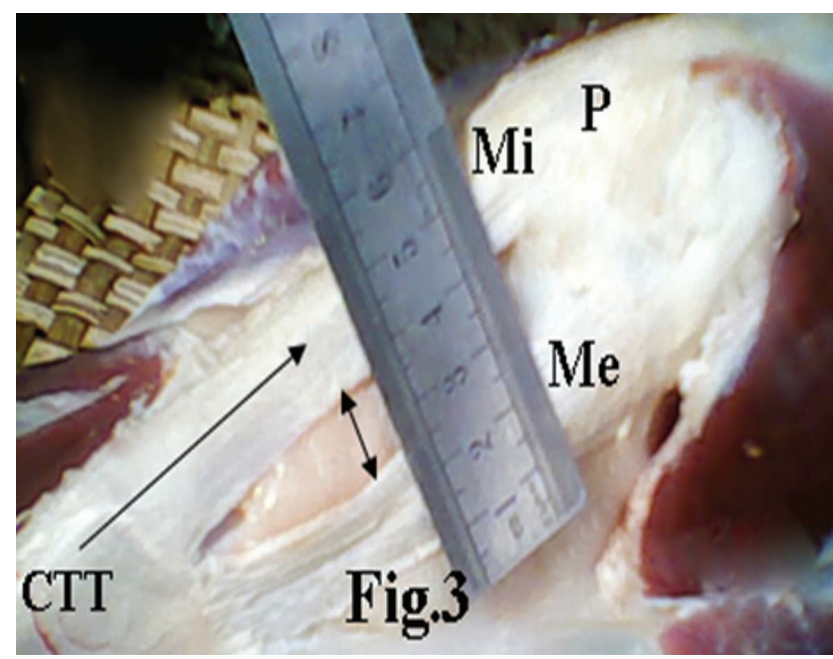

Fig. 3. Measurement of patellar ligaments of indigenous cattle; cranio-medial view. Me. Medial patellar ligament; Mi. Middle patellar ligament; La. Lateral patellar ligament; CTT. cranial tibial tuberosity; P. Patella.

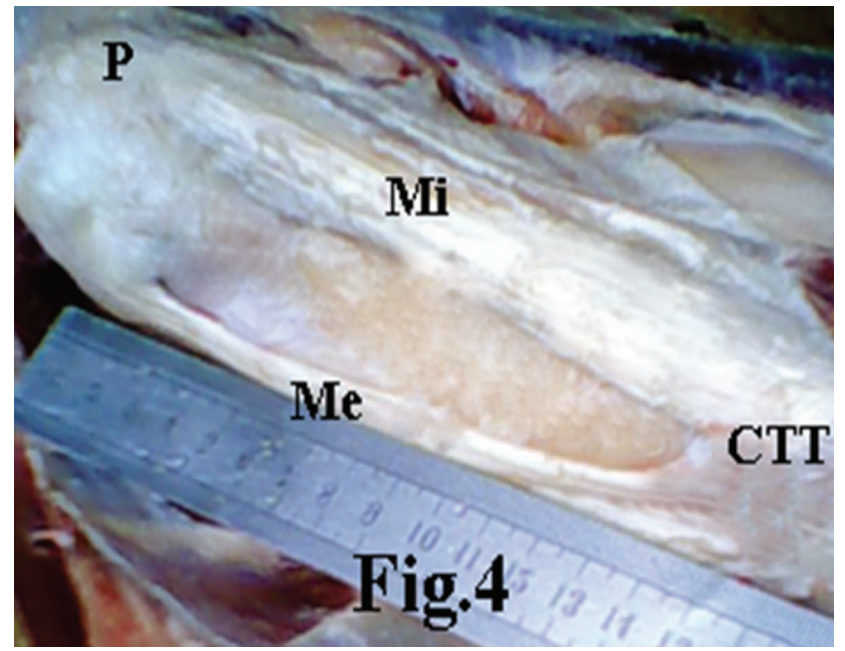

Fig. 4. Measurement of patellar ligaments of crossbred cattle; cranial view. Me. Medial patellar ligament; Mi. Middle patellar ligament; CTT. cranial tibial tuberosity; P. Patella.

\section{RESULTS AND DISCUSSION}

The medial patellar ligaments of indigenous and cross bred cattle were the length of $10.519 \pm 0.429 \mathrm{~cm}$ and $12.366 \pm 0.710 \mathrm{~cm}$ and the width of $2.430 \pm 0.232 \mathrm{~cm}$ and 2.890 $\pm 0.234 \mathrm{~cm}$, respectively. There were significantly different in length $(\mathrm{p} \leq 0.05)$ and in width $(\mathrm{p} \leq 0.05)$ of medial patellar ligament between indigenous and crossbred cattle. The width of medial patellar ligament is clinical important because whole width to be incised during medial patellar desmotomy. Medial patellar ligament is thin, ribbon like flattened, and weaker than middle and lateral patellar ligament. It is attached to parapatellar fibro-cartilage and ends on the tuberosity of the cranial tibial tuberosity at the medial side and located at the medial aspect of the stifle joint (Marudwar \& Kulkarni).

The grooves width from middle to medial patellar ligaments for indigenous and crossbred cattle were $1.356 \pm 0.160 \mathrm{~cm}$ and $1.828 \pm 0.186 \mathrm{~cm}$ respectively. Medial patellar ligament is widely and distinctly $(1.356 \pm 0.160 \mathrm{~cm}$ and $1.828 \pm 0.186 \mathrm{~cm}$ ) separated from middle patellar ligament and topographically medial patellar ligament was located just medial to this groove at the medial aspect of the stifle joint. The distances/the measurement of highest groove width from cranial tibial tuberocity toward the patella were $4.234 \pm 0.269 \mathrm{~cm}$ and $5.645 \pm 0.398 \mathrm{~cm}$ in indigenous and cross bred cattle respectively and the parameter was significantly different $(\mathrm{P} \leq 0.05)$ between breeds. This groove is wider at the proximal extremity and converges distally toward the cranial tibial tuberosity (Tyagi \& Singh; Getty).

These parameters of the groove width and the location of highest groove width from the level of most cranial bulging of cranial tibial tuberosity to the patella are of surgical importance as a guide for the accurate site of the incision / stabbing of knife or blade without any damage of middle patellar ligament during medial patellar desmotomy. The level of most cranial bulging of cranial tibial tuberosity is very important even in live animals as a guide to tracking the medial patellar ligament.

Same parameter in buffalo has been estimated to be about $2 \mathrm{~cm}$ above the insertion of the medial patellar ligament at tibial tuberosity (Sutradhar), in bovine about 1 to $2 \mathrm{~cm}$ above the upper extremity of tibia (Muradwar \& Kulkarni). The ligament incised about half an inch away from the medial edge of the medial tibial condyl in ponies (Sharma,1980). The ligament may be cut at any place along the length from the patellar fibro cartilage to tuberosity for bovine medial patellar desmotomy (Sahu \& Mohanty, 1972). Present study was suggested that longer distance than previous findings because measurement was taken from level of most cranial bulging of cranial tibial tuberosity.

The length and width of middle patellar ligament for indigenous were $10.230 \pm 0.382$ and $2.019 \pm 0.258$; for cross bred cattle were $11.580 \pm 0.724$ and $2.330 \pm 0.205 \mathrm{~cm}$. Topographically, middle patellar ligament was located along the cranio-midline of the stifle joint. This ligament has structural interrelationship with medial patellar ligaments. Surgical importance is that 
UDDIN, M. M.; REZA, S. M.; ISLAM, N. K.; MIAZI, O. F. \& AHMED, S. S. U. Surgical anatomical measurements of patellar ligaments for blind method of medial patellar desmotomy of cattle during upward patellar fixation in Bangladesh. Int. J. Morphol., 27(2):311-315, 2009.

Table I. Surgical anatomical measurements of patellar ligaments of stifle joints in cattle (mean $\pm \mathrm{SD}, \mathrm{n}=50)$.

\begin{tabular}{llcrr}
\hline Parameters & & Indigenous $(\mathbf{c m})$ & Crossbred $(\mathbf{c m})$ & T $(\mathbf{p})$ \\
\hline \multirow{2}{*}{ Length } & Medial patellar ligament & $10.519 \pm 0.429$ & $12.366 \pm 0.710$ & $15.722(0.000)$ \\
& Middle patellar ligament & $10.230 \pm 0.382$ & $11.580 \pm 0.724$ & $11.616(0.000)$ \\
\multirow{2}{*}{ Width } & Lateral patellar ligament & $9.360 \pm 0.339$ & $10.636 \pm 0.601$ & $13.072(0.000)$ \\
& Medial patellar ligament & $2.430 \pm 0.232$ & $2.890 \pm 0.234$ & $9.903(0.000)$ \\
& Middle patellar ligament & $2.019 \pm 0.258$ & $2.330 \pm 0.205$ & $5.155(0.000)$ \\
Grove & Lateral patellar ligament & $3.056 \pm 0.226$ & $3.608 \pm 0.368$ & $9.025(0.000)$ \\
width & Middle to lateral patellar ligament & $1.356 \pm 0.160$ & $1.828 \pm 0.186$ & $13.570(0.000)$ \\
$\begin{array}{l}\text { Highest groove width between middle and medial patellar } \\
\text { ligaments from the le vel of the most cranial bulging of the } \\
\text { cranial tibial tuberosity towards patella. }\end{array}$ & $0.254 \pm 0.083$ & $0.474 \pm 0.094$ & $12.327(0.000)$ \\
\hline
\end{tabular}

transaction of this ligament would render the animal permanently lame and the data will help the surgeon to avoid any damage during medial patellar desmotomy. Among three patellar ligaments, middle patellar ligament is thick and strong as compared to other two ligaments (Tyagi \& Singh). It extends from the cranial part of the apex of the patella to the distal part of the cranial tibial tuberosity (Getty).

Lateral patellar ligament of indigenous and crossbred cattle was found to have a length of $9.360 \pm 0.339$ and 10.636 $\pm 0.601 \mathrm{~cm}$ and width of $3.056 \pm 0.226$ and $3.608 \pm 0.368 \mathrm{~cm}$ respectively. The lateral patellar ligament extended from the lateral part of the cranial surface of the patella to lateral part of the tuberosity of the tibia and located lateral aspect of the stifle joint. This ligament had wider proximal end than distal end which attached with the lateral part of cranial tibiial tuberosity. The data of this ligament has less clinical important though has close interrelationship with middle patellar ligament.
The groove width from middle to lateral patellar ligaments were $0.254 \pm 0.083 \mathrm{~cm}$ and $0.474 \pm 0.094 \mathrm{~cm}$ in indigenous and cross bred cattle respectively. These two ligaments were close together and non palpable groove due to presence of loose connective tissues.

Difference of all parameters was statistically highly significant $(\mathrm{P} \leq 0.05$, table 1$)$ between indigenous and crossbred cattle, and parameters were significantly lower in indigenous than crossbred cattle.

As earlier stated, there is no previous information on these parameters in indigenous and crossbred cattle, nor in any other domestic animals in Bangladesh with which comparisons could be made. We therefore believe that the data presented above will form a vital baseline for the prefect medial patellar desmotomy in both indigenous and crossbred cattle.

UDDIN, M. M.; REZA, S. M.; ISLAM, N. K.; MIAZI, O. F. \& AHMED, S. S. U. Mediciones anatómicas quirúrgicas del ligamento patelar por técnica ciega en la desmotomía medial patelar de ganado durante la fijación superior de la patela en Bangladesh. Int. J. Morphol., 27(2):311-315, 2009.

RESUMEN: El estudio fue dirigido a determinar la ubicación exacta de la incisión y el ancho necesario de la incisión para corregir el problema de la fijación superior patelar durante la técnica ciega de la desmotomia medial patelar. Se tomaron y analizaron medidas del ligamento patelar en la rodilla de 50 bovinos indígenas y 50 bovinos mestizos de criadero, sacrificados sin aparentes trastornos músculoesqueléticos. El promedio de longitud y ancho lateral, central y medial del ligamento patelar para el ganado indígena fueron 9,360 $\pm 0,339$ y $3,056 \pm 0,226 ; 10,230 \pm 0,382$ y $2,019 \pm 0,258 ; 10,519 \pm 0,429$ y $2,430 \pm 0,232$, y para el ganado mestizo $10,636 \pm 0,601$ y $3,608 \pm 0,368$; $11,580 \pm 0,724$ y $2,330 \pm 0,205 ; 12,366 \pm 0,710$ y $2,890 \pm 0,234 \mathrm{~cm}$, respectivamente. El promedio del ancho del surco para el ganado bovino indígena y el mestizo entre el ligamento medio y ligamento medial fue $1,356 \pm 0,160$ y 1,828 $\pm 0,186 \mathrm{~cm}$, y el máximo ancho del surco entre el ligamento medio y ligamento medial patelar desde el nivel más craneal del abultamiento de la tuberosidad tibial craneal en dirección hacia superior fueron 4,234 $\pm 0,269$ y $5,645 \pm 0,358 \mathrm{~cm}$, respectivamente. Los parámetros medidos fueron significativamente diferentes $(\mathrm{p} \leq 0,05)$ entre el ganado indígena y el ganado mestizo. Este estudio puede sugerir que la incisión puede ser hecha 4,234 $\pm 0,269$ y 5,645 $\pm 0,398 \mathrm{~cm}$ proximalmente desde el nivel más craneal del abultamiento de la tuberosidad tibial craneal hasta el surco entre el ligamento patelar medio y medial. $2,430 \pm 0,232$ y $2,890 \pm 0,186 \mathrm{~cm}$ fue la media del ancho del ligamento medio a ser cortada durante la técnica ciega de la desmotomía medial patelar del ganado indígena y mestizo respectivamente, durante la corrección quirúrgica de fijación superior patelar.

PALABRAS CLAVE: Anatomía quirúrgica; Desmotomia medial patelar; Fijación superior patelar; Bovino. 
UDDIN, M. M.; REZA, S. M.; ISLAM, N. K.; MIAZI, O. F. \& AHMED, S. S. U. Surgical anatomical measurements of patellar ligaments for blind method of medial patellar desmotomy of cattle during upward patellar fixation in Bangladesh. Int. J. Morphol., 27(2):311-315, 2009.

\section{REFERENCES}

Ali, M. A. \& Hashim, M. A. Upward fixation of patella in Cattle. Bangladesh Vet. J., 18:69-70, 1984.

Dyce, K. M.; Sack, W. O. \& Wensing, C. J. G. Text Book of Veterinary Anatomy. $2^{\text {nd }}$ Ed. Philadelphia, Saunders, 1996.

Getty, R. Sisson and Grossman's The Anatomy of the Domestic Animals. $5^{\text {th }}$ Ed. Philadelphia, Saunders, 1975.

Hossain, M. A. \& Haque, M. A. Medial patellar desmotomy in bovine upward patellar fixation. Bangladesh Vet. J., 6:14-6, 1989.

Marudwar, S. S. \& Kulkarni, P. E. Simpler and safer technique for locating and cutting the medial patellar ligament. Indian Vet. J., 57:419-21, 1980.

Rahman, M.; Rahman, A.; Routledge, R. F. \& Islam, A. Bovine upward fixation of patella in Bangladesh. Livestock Adviser, 9:9-11, 1984.

Ramakrishna, O. Comparative Studies on the treatment of chronic Subluxation of the patella in buffaloes. Indian Vet. J., 49(11):1150-3, 1972.

Sahu, N. \& Mohanty, K. Diverse Surgical approaches for bovine upward fixation of patella. Orissa Vet. J., 7:20-2, 1972.

Sahu, S. Experimental section of medial and anterior patellar ligaments in bovine:a clinical study. Indian Vet. J., 48:645-7, 1971.

Sharma, K. B.; Joshi, Y. G. \& Tanar, P. K. A report on the incidence of Upward fixation of patella (Stringhalt) in bovines of Udaipur area in Rajasthan. Indian Vet. J., 61:689-91, 1984.

Sharma, S. P. Medial patellar desmotomy as a treatment of stringhalt in ponies. Indian Vet. J., 57:684-5, 1980.

Sutradhar, B. C. Medial patellar desmotomy in the Buffalo on upward Patellar fixation. Bangladesh Vet. J., 20(1):25$8,2003$.

Tyagi, R. P. S. \& Singh, J. Ruminant surgery. $2^{\text {nd }}$ Ed. New Delhi, CBS Publishers \& Distributors, 2001.

Tyagi, R. P. S.; Krishnamurthy, D. \& Kharole, M. U. Studies on histopathology of ligaments in bovine animals affected by upward fixation of the patella. Vet. Rec., 93:362-4, 1973

\section{Correspondence to:}

Syed Sayeem Uddin Ahmed

Assistant Professor

Department of Medicine and Surgery

Faculty of Veterinary Medicine

Chittagong Veterinary and Animal Sciences University.

Khulsi; Chittagong-4202.

BANGLADESH

Phone: +88-0171-3368439

Fax- +88-031-659020

E-mail: sayeem_2000@yahoo.com

Received: 12-11-2008

Accepted: 31-03-2009 
